\title{
GREY SEALS OF THE FARNE ISLANDS
}

\section{INTRODUCTION}

The Atlantic Grey Seal, Halichoerus grypus, is one of the world's rarer mammals. In 1954 R. M. Lockley estimated its total population as $33,500 *$ and there is no reason to suppose there has since been an increase. About 20,000 of these seals live in colonies around the coasts of the British Isles, all on the north and west, except for one colony which inhabits the Farne Islands, a National Trust nature reserve off the Northumberland coast.

For years grey seals from these islands have been accused of causing damage to salmon and salmon nets in the Tweed estuary and on the Northumbrian coast. In 1958, in spite of a reasoned protest by the Natural History Society of Northumberland, Durham and Newcastle upon Tyne, the Government amended the Grey Seals Protection Act, 1932, and thus authorized the killing of a certain number of seal calves in November and December, that is during the close season.

On 3rd July, 1958, the Fauna Preservation Society, in a letter to the Minister of Agriculture, Fisheries and Food, gave its opinion that the killing of fifty or more calves in the Farne Islands would be futile, because it would have no effect on the future number of adult seals. There was such a high mortality among young seals that 60 per cent did not survive their first year. This meant that thirty of the fifty young seals which it was proposed to slaughter would not in any case reach one year old. Calculation would show that if every young seal were slaughtered for ten years, the total adult population would only be reduced by about one-half. We believed, therefore, that the proposed killing would be a waste of time and money and suggested that the proper way of dealing with seals which damage salmon nets was by sustained shooting at the place where the seals were doing the damage. This would be far more effective in protecting the fishermen's interests and would avoid disturbing the splendid Farne Islands colony of the rare grey seal.

The Minister replied that he had made a careful note of our views. Nevertheless, the killing of young seals took place.

On 10th December, 1958, the Council for Nature expressed its disapproval of the slaughter policy, noting that the Berwick Salmon Fisheries Company had announced their best grilse

* Oryx, Vol. II, No. 6. The Atlantic Grey Seal, by R. M. Lockley. 
salmon catches for fifty years. The Council pointed out that Britain has a special responsibility towards this species. It believed that no further killing should be carried out unless research over a number of years provided substantial evidence to justify it.

Our Society has entirely failed to discover any ecological justification for the policy of killing these baby seals. Its supporters are almost all either political or parochial in their outlook. All that they have established is that some seals eat some salmon and sometimes damage some fishermen's nets. On even a national view, ignoring the rarity of the grey seal as a species, we believe that there is no sound basis for the disruption of one of the most fascinating sights and opportunities for study in the whole field of British mammals.

Now, so that our members may see the whole picture, we publish two articles, one by Mrs. Grace Hickling, joint honorary secretary of the Natural History Society of Northumberland, Durham and Newcastle upon Tyne, the other by Dr. E. A. R. Ennion, Director of Monkshouse Bird Observatory (opposite the Farne Islands).

\section{The Grey Seals of the Farne Islands}

\section{By Grace Hickling}

The history of the Farne Islands colony of the grey seal, Halichoerus grypus, shows very clearly the paucity of information which has been available, until recently, about one of Britain's largest mammals.

The Farnes are a group of small islands some 10 miles south of Berwick-on-Twced, the actual breeding islands-Staple Island, the North and South Wamses and the Brownsmanbeing about $3 \frac{1}{2}$ miles from the mainland. Weather conditions may, for long periods, make landing impossible, but, despite this, the Farnes are probably the most accessible British colony and are, therefore, particularly suitable for the study of the life history of the grey seal.

Unfortunately, it was not until 1951 that scientific study was started, and it is the lack of accurate information which makes it so difficult to assess the possible effect of the increased number of seals on both salmon and inshore fishing. It is particularly unfortunate that, before 1956, there are no figures either for the number of calves born each year-a figure which forms a good guide to colony size - or for the calf mortality rate. 
It is known that the colony has existed for at least 800 years and that during the period of the monastic House of Farne seals were killed regularly ; moreover, at the end of the eighteenth century, when the islands were let to the Blacketts, the crop of calves removed annually was so great that the colony was in danger of extermination. This danger was averted when, in 1881, the newly-formed Farne Islands Association (now administered by the local committee of the National Trust) instituted complete protection for birds and seals. Nevertheless, even as late as 1911, a seal was still a rare sight and it is probable that there were then not more than 100 in the colony. The build-up continued only slowly and by the nineteen-thirties the numbers were probably between 600 and 800 .

There is no information about the period from 1939 to 1948 , although the single count made in 1949 suggested a considerable increase. By 1950, although again there is all too little evidence, it was apparent that there were at least 2,270 seals. It was not until 1.956 that there was any systematic attempt to count the number of calves born and the number which die on the nurseries. The 1956 count, carried out by the Northumberland and Durham Natural History Society, was made possible by a three-year grant from the Nature Conservancy which enabled the Society to enlarge the scope of its investigations into the seals' life history. In that year at least 746 calves are known to have been born, of which seventy-nine died. The total for 1957 was 854 , with 139 deaths, giving a mortality rate of $16 \cdot 3$ per cent as compared with the 1956 rate of $10 \cdot 6$ per cent. Bad weather, and other circumstances, hampered work in 1958 and there are no figures after the end of November, by which time 748 calves had been born and 104 had died with a resultant mortality rate of 13.9 per cent. It should be explained that in 1958 breeding as a whole started at least a week later than usual and this was particularly obvious on the Brownsman where, on 29th November, there were only twenty-one calves as compared with sixty-five on 28th November, 1957. Storms throughout December and January prevented further visits, but increased the natural mortality, and although a few uncounted corpses were found on 31st January, many had obviously disappeared. No comparison can, therefore, be made with previous figures, but it seems probable that the colony now numbers between 3,200 and 3,400 and that there is an increasing calf mortality rate which will lead, in time, to a natural reduction in the size of the colony.

Scientific study of the Farne seals was started by the 


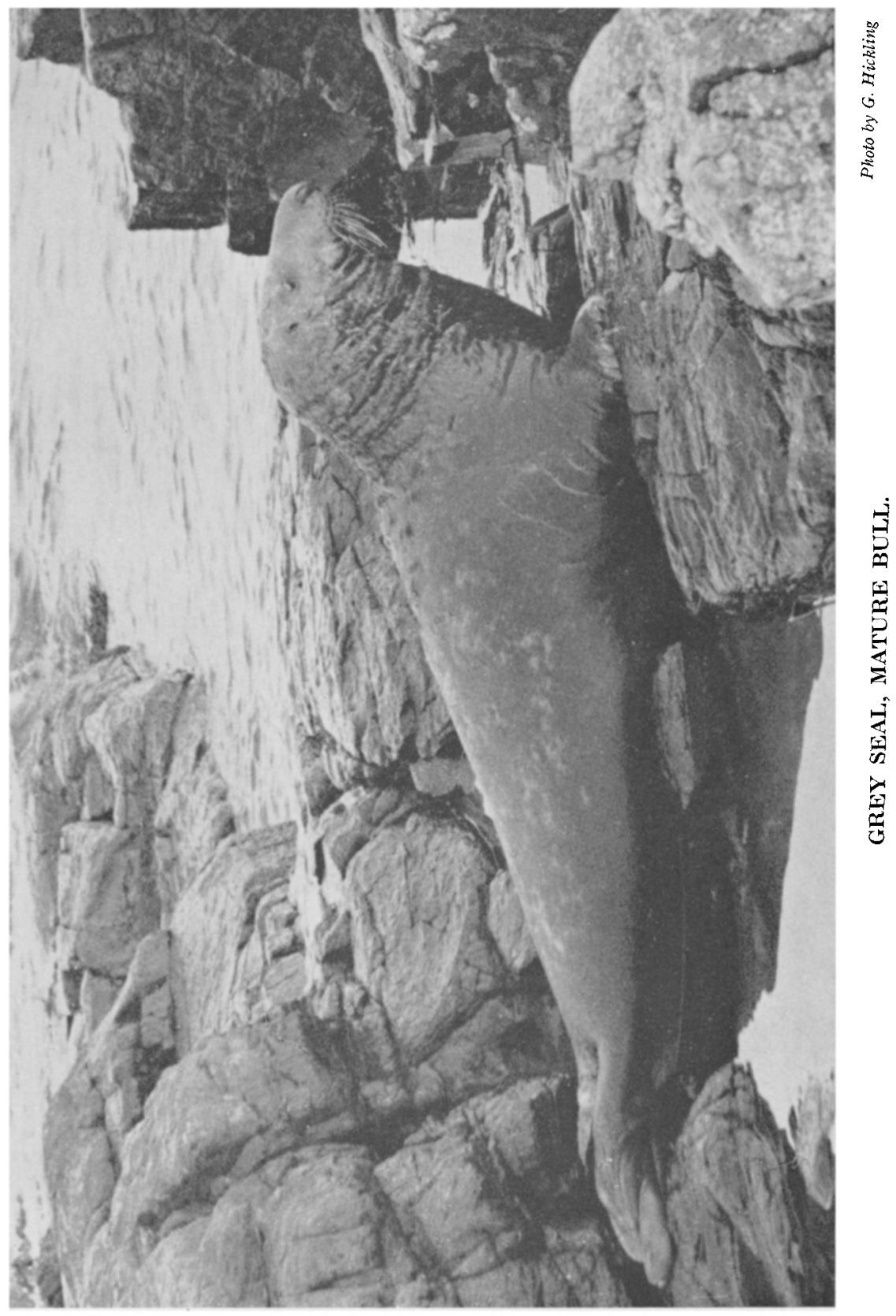




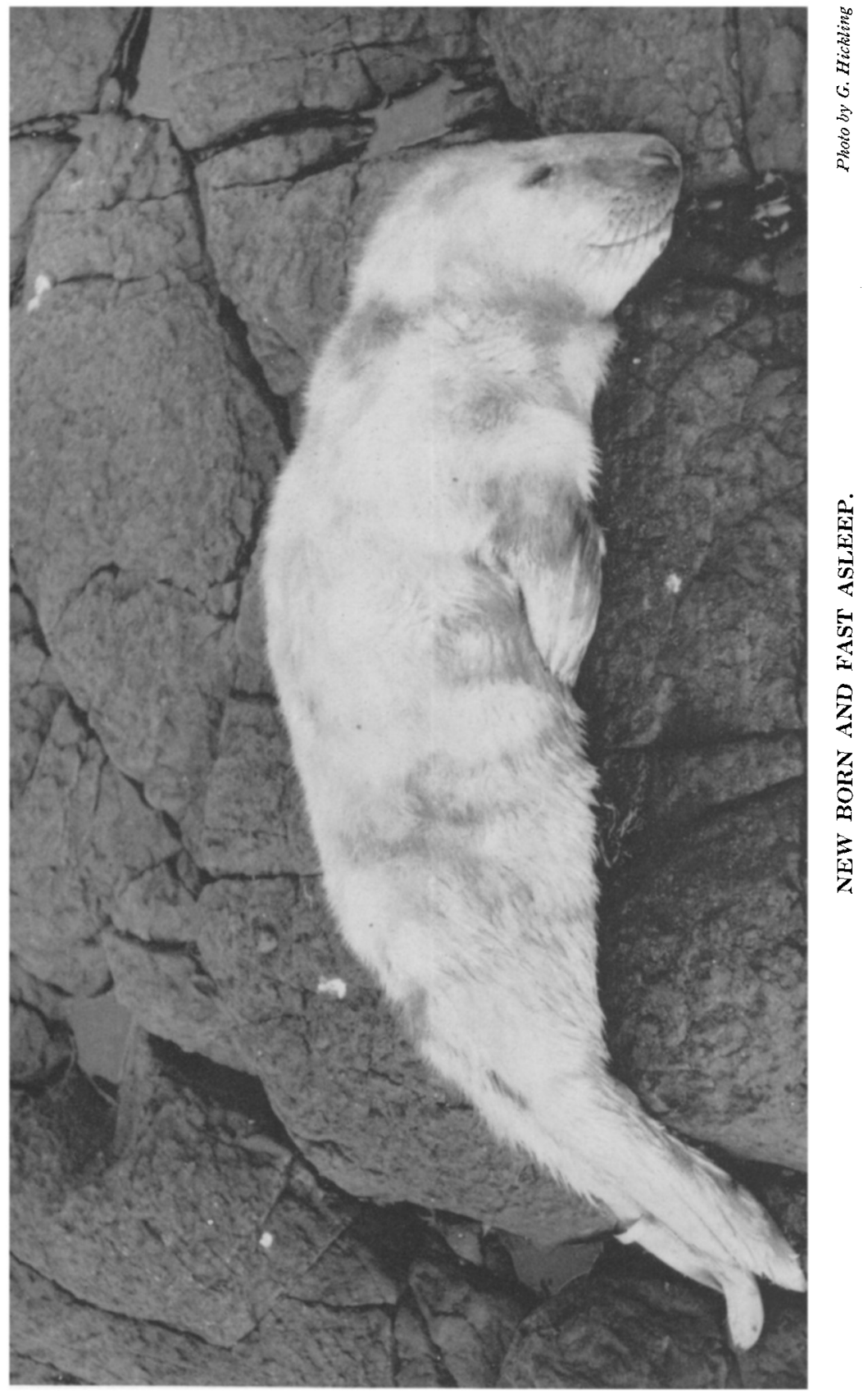




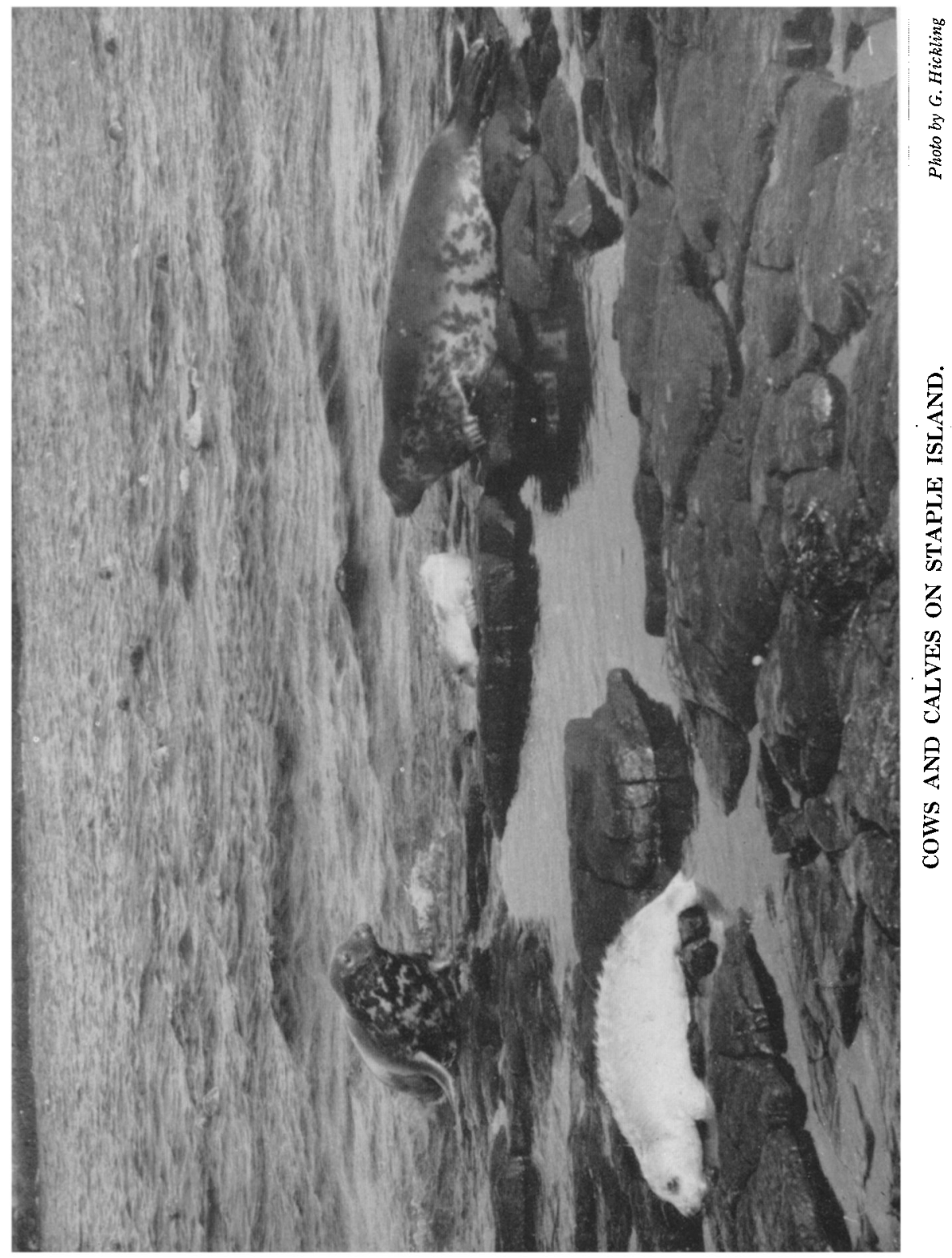


Northumberland and Durham Natural History Society on 16th December, 1951, when members of the Society tagged ten seal calves. This was the first attempt ever made to tag grey seals and the recovery, fourteen days later, of calf No. 1 at Stavanger, in Norway-400 miles away-led to a general marking scheme which has its headquarters at the Zoological Society of London. Since that date 1,394 calves have been marked on the Farnes and there have been recoveries from a number of places. 'These include: Norway, four; Holland, two ; Denmark, one ; Germany, one ; Faeroes, one ; east coast of England (as far south as Norfolk), twenty-one; east coast of Scotland (from Berwick to Banffshire), twenty-three. It is worth noting that, with the exception of an animal shot on the River Tay when a year old, all the calves recovered have been under nine months and the majority have been less than ten weeks. These recoveries indicate that there is a definite dispersal movement of calves of the year although there is, so far, no information about the movements of adults.

Tags are fixed to a hind flipper, the original tag being a stainless steel clip. The next was a monel metal ring, but this proved too small for adults and in 1958 a new type-a plastic disc-was tried. This is similar to the marks used on harp and hooded seals in the Arctic and on harbour seals in Holland, and experience so far suggests that it will be more successful than the previous tags.

Weighing of calves was started in 1952 and has already yielded valuable information. It has been found that birth weights vary from 20 to $38 \mathrm{lb}$. and that calves increase by 60 to $70 \mathrm{lb}$. in the first three weeks of life while, after weaning, they decrease at the rate of about $1 \cdot 2 \mathrm{lb}$. a day. Furthermore, results suggest that weight at weaning is an important factor in ensuring survival during the first year of life, for a healthy calf of four to five weeks will weigh 80 to $90 \mathrm{lb}$., while a yearling only weighs between 85 and $104 \mathrm{lb}$. Calves obviously find it very difficult to catch enough food to keep themselves alive, let alone put on weight, and it is probable that some of the seals caught in salmon nets are youngsters seeking an easy source of food. Certainly the only ones known definitely to have come from the Farnes were calves.

Seals are gregarious animals, and although some of the other islands are perfectly suitable for nurseries, they are at present unoccupied, with the result that certain parts of Staple Island and the North Wamses become overcrowded. Many of the calves in these areas have been found to be underweight and 
this leads to an increased mortality rate: it seems likely, therefore, that artificial thinning-out of the colony may simply mean that more calves reach maturity.

As will be appreciated, the Nature Conservancy's recommendation for an experimental annual cull of $\mathbf{3 0 0}$ calves caused very grave concern in the Natural History Society and arrangements for the killing were watched closely.

It was decided that only weaned calves should be killed and that, as the killing was experimental, it should take place on the North Wamses, the numbers to be killed being considerably less than 300. The main objects of the experiment were to discover (1) if killing parties could land easily on the Farnes ; (2) if calves could be killed humanely and, if so, how many could be dealt with on each visit; and (3) how to dispose of the corpses.

There were three possible periods for the killing, namely the weeks beginning 17th November and 1st and 15th December. The unexpectedly late breeding season meant the abandonment of the November date, while the weather on 1st and 2nd December was unfavourable, so that it was not until 3rd December that an expedition was possible. Conditions were ideal; there was no swell and only a light wind. Two and a half hours were spent ashore. The party consisted of a qualified slaughterman, two senior officers of the Ministry of Agriculture, Fisheries and Food (one of them a veterinary surgeon), an official observer from the National Trust and six Seahouses fishermen. These last, though disapproving thoroughly of the killing, had agreed to act as porters.

It soon became evident that four- to five-week-old calves were far from easy to kill. The weapon used was a captive bolt humane killer and the main problem was to hold the animal still. Ten calves were killed and three died instantaneously; in one instance the first shot simply inflicted a scalp wound and in other cases two or more shots were needed. The whole affair was most distressing, but it must be emphasized that everything possible was done to minimize the calves' suffering.

The next problem was the disposal of the corpses. For various reasons it was considered undesirable to leave these on the islands and, accordingly, two methods of disposal were tried. A few of the bodies were simply slit open and dropped into the sea ; the remainder were carried to the boats, put into weighted sacks and then sunk in deep water. This last took a considerable time, for the walk from the North Wamses to the landing place is over slippery rocks and seaweed. 
Public opinion, the refusal of the local fishermen to accompany any future expeditions and, most important, unfavourable weather, prevented further killing and the question now arises as to what extent was the experiment a success ?

The answer seems to be that it was, on the whole, a failure. The difficulty of getting out to the Farnes in winter was clearly demonstrated and this, combined with the fact that only ten calves could be killed on a day of perfect weather, indicates that it would be extremely difficult to kill 300 calves a year. Moreover, the proviso made in the Order authorizing the killing, that calves must die instantaneously, was not always fulfilled. The finding, a week or two later, of two of the dead calves on the beach at Seahouses shows that even the disposal of corpses is far from easy.

\title{
Should the Seals be Killed?
}

\author{
By Dr. E. A. R. EnNIon
}

(Reproduced with kind permission from Farm and Country)

Scientist, crofter, humanist, that wise and scrupulously fair investigator, Dr. Frazer Darling, recalls in his $A$ Naturalist on Rona that, in 1934, at least $\mathbf{1 7 7}$ grey Atlantic Seals were killed on the coast of Cornwall "to appease the feelings of the fishermen ", and, further, that " this great and unnecessary slaughter . . . received official condonation although, in part at least, it was a flagrant breach of the law ; and none of the victims was submitted to scientific examination". Whatever the merits or demerits of this Roman holiday a unique opportunity was missed. Had a proper analysis of the stomach contents of this big sample of Atlantic seals been made, it might well have saved the virtual repetition of the affair on the Farne Islands in 1958, when a number of seal calves were slaughtered, "experimentally," by order of the Ministry of Agriculture, Fisheries and Food; this time to appease the feelings, principally, of the salmon-netters of the Tweed. There was no point in making stomach analyses in this case, for none of the victims had tasted anything more innocuous than mother's milk.

The seal colony on the Farnes, which belong to the National Trust, is unique at least in the sense that nowhere else is it possible to see so closely and conveniently such a great gathering of grey seals. They attract literally hundreds of visitors both out of, and especially during the breeding season (end-October to mid-December), when one can walk about among dozens of 
the little white calves, or pups, and watch the whole fascinating pageant of a great seal colony at close quarters.

\section{Local Opposition}

A full and long-term programme of research into the movements, habits and biology of these seals (whose economy is at present far from fully understood), initiated four years back by the Natural History Society of Northumberland, Durham and Newcastle upon Tyne, is in progress. It involves the tagging and weighing of hundreds of young seals and the periodic counting of the adults. So, when the executioners set forth, feelings very naturally ran high. The vast majority of the local fishermen and most decent sensible people in the neighbourhood were strongly opposed to it and felt that the case against the seals was far from proven. And I think they were right.

Many reports, some factual, some sensational, appeared in the local and in the national Press, one of which-I feel sure by both reporter and informant in all good faith-alleged that "The 3,200 seals on the Farne Island sanctuary ate $£ 800,000$ worth of fish in a year", on the estimate of a Tweed fishery owner and fish merchant, who went further and told a gathering of Rotarians that " since the Farne Island colony had grown from 100 in 1920 herring had disappeared from the coast and the catches of white fish had become poor ".

This, since it has the semblance of truth (and is true in some respects) and was reported in a responsible newspaper, is likely to be taken at its face value by those who are only too easily gulled by the printed word. If the inference is that 3,200 seals live on the Farnes and deprive the public annually of $£ 800,000$ worth of fish, and that, either having eaten all the local herrings or driven them away, they are now exercising a baneful influence on white fish, then this allegation is untrue in all material respects !

Firstly, the number of seals. A figure of 3,200 is estimated for the whole colony-calves of the year, two-year-olds, immature and adult cows and bulls. This was arrived at by a method suggested after years of experience among the grey seals of Wales by Mr. R. M. Lockley, i.e. by multiplying the year's crop of baby seals by four. In round figures the number of calves born (in 1956) was 750-of which eighty died in infancygiving a colony population of 3,000 .

\section{Counting the Farnes Seals}

In many of their haunts it is exceedingly difficult to count grey seals. They breed in inaccessible caves and haul out on 
equally inaccessible skerries. But this is not so on the Farnes, where it is possible to count both calves and adults with very fair accuracy. Eighteen counts of adult seals were made at intervals during 1956 as part of the research programme. Fewer were found on the islands during the summer months, and even before and after the breeding season when the greatest concentration might have been expected, at no time did their numbers exceed 1,200 -less than half the total colony strength of 3,000. Why the discrepancy?

It has long been noted that very few calves of the year are seen on the Farnes once breeding is over. Nor, as has been discovered from these very investigations, are even the twoyear-olds to be found in significant numbers. Research again is finding the answer. Young seals, ringed on the Farnes, have been recovered not only from the Scots coast as far north as Banffshire, and south as far as Norfolk, but from as far away as The Faeroes and Norway, and only one of all these young seals so far recovered was more than fifteen weeks old! The odd one, one of two recovered at St. Cyrus, Kincardineshire, was $8 \frac{1}{2}$ months old-approaching his first birthday. So it looks as if these baby seals leave the colony almost as soon as they enter the water and do not return until at least two years old. They, the one- and two-year-olds, obviously are not robbing the local fisheries; and the resident colony strength should be halved, i.e. 1,500 rather than 3,000. This is still a higher figure than the adult count suggests.

It seems probable (but not proven) that some of the adults also wander away, perhaps to form the odd twos and threes, and, maybe, the groups of up to twenty, that one sees at many points on the north-east coast, including those haunting the mouths of the Tweed and the Tay and the Coquet, but also much farther afield. Indeed, if immature Farne seals visit The Faeroes and Norway, which possess grey seal colonies of their own, what is to prevent Norwegian and Faeroese seals visiting the Tweed? Butchering baby seals on the Farnes would not have much effect on them!

\section{A Mistaken Notion}

It is known, furthermore, that the adult bulls when breeding, and the adult cows while suckling, feed very little, if at all. They live on their reserves. Hence, when the colony strength is at its highest, the feeding demand must be almost at its lowest. In short, the notion of 3,200 seals guzzling fish round 
the Farnes must be taken with a fair-sized pinch of salt ! It is very, very wide of the mark.

And what of those $£ 800,000$ ? One must assume this has been calculated on the value of the weight of fish caught by these alleged 3,200 seals in the sea. It would be rather uncharitable to charge to the seals' account the considerable profits made by the netsmen and the fishermen, auctioneers, distributors and fishmongers, the middlemen that stand between the fish in the sea and the fish on the plate. And is our fisheries owner quite sure that he would, in fact, catch all those fish that the seals hadn't nipped in and caught before him? Assuming he $i s$, then his figure of $£ 800,000$ for 3,200 seals14s. a day each-is about right for fish at a wholesale price of around $12 s$. a stone.

Both Dr. Harrison Matthews and Mr. G. A. Stevens, who probably know more about seals' diets than anyone else, put the average adult grey seal's daily needs at a little over $15 \mathrm{lb}$. But they also state, and Lockley and Frazer Darling agree, that by far and away the bulk of its diet consists of inshore rock fishes like saithe, pollack and wrasse, while on the Farnes the lumpsucker, or " sea-hen", is its commonest dish. I fancy, even if some means could be devised for taking this sort of fish on a commercial scale from the kind of sea-bottom they normally frequent, a merchant would be more than delighted to find buyers at 12s. a stone! Even the seals themselves reject the coarse lumpsucker skins (so would you if you saw them), rough as carborundum and studded like football boots. We find plenty of them cast up by the tide.

No, sir! Fine figures won't do. We must both strive for chapter and verse. Apart from the rogues that establish themselves in estuaries and damage the nets-and those you should shoot (and could do so quite legally outside the breeding season) - it is doubtful whether one seal in a hundred takes salmon, or herring, or commercial white fish to any significant extent. It has been found, in any case, that 25 per cent of these estuarine marauders are common, and not grey, seals ; and is at least likely that Orcadians and Shetlanders, Faeroese and Norwegians might be found among the rest. It would seem, therefore, illogical, if not downright dishonest, to " take it out " of the seal calves on the Farnes.

As much as $£ 800,000$ is fantasy : a few hundred pounds a year perhaps-and some big holes in the nets. Are not your brother-fishermen at sea having their whole net cut away through the carelessness of foreign trawlers and with small 
prospect of redress ? The fact that each one of these past five years appears to have been a "best ever" for netted salmon should be some consolation. And, in a district where half the people one meets are never really happy unless they are killing something, it should not be all that difficult to organize the putting paid to those rogue seals. It is being done elsewhere. As to the deterioration in white fish and herring catches, might not over-fishing in the North Sea generally, and the taking of undersized immature fish by foreign boats in particular, have something to do with it? That is the local fishermen's opinion.

It may strike one as strange that a grey seal of 4 or 5 cwt.a big bull might turn the scale at over 6 cwt., the weight of four grown men-should need only some $15 \mathrm{lb}$. of fish a day. Indeed, four men would want a good deal more than $4 \mathrm{lb}$. each net if, like the seal, they ate their rations neat-untrimmed, uncooked, the vegetables just as they came from the garden, the meat just as it came on the hoof, peel, pips, husks, bones, everything-for the seal, so far as we know, rejects nothing but lumpsucker skins. It is an excellent economist. Dr. Harrison Matthews, scientific director of the London Zoo, shows why in his fascinating account of seal metabolism in British Mammals.

Seals, on the Farnes and wherever else they can haul out in peace, spend long periods at low tide resting-" Sometimes I sits and thinks and sometimes I just sits." Apart from the essential internal tick-over, digestion and so forth, they are doing no work. Neither, with an insulating layer of blubber up to $1 \frac{1}{2}$ in. thick, do they lose appreciable heat. When, having emptied their lungs to reduce buoyancy, they dive and start hunting for fish, their movements are as effortless as a frogman's, so they need very little replenishment. A tiny shrew, by contrast, and weighing $\frac{1}{3} \mathrm{oz}$., has to eat more than its weight every day of worms and insects.

\section{Ten Heart-beats a Minute}

Furthermore, on diving, a seal's metabolism is further reduced by the slowing of its heart-beat from 150 on the rocks to only 10 beats a minute underwater. Various other equally fascinating gimmicks contribute to its being able to stay under for a quarter of an hour at a time; and to counteract depth pressure; and to keep oxygen supplied to the brain to prevent unconsciousness. A scapegoat's bullet seems a sorry end for such an interesting beast, which is one of the most abstemious feeders of all mammals. 